\title{
A REVIEW OF EMPIRICAL STUDIES ON FDI DETERMINANTS
}

\author{
Arben SAHITI ${ }^{1}$, Skender AHMETI ${ }^{2}$, Hysen ISMAJLI ${ }^{3}$ \\ ${ }^{1}$ University "Kadri Zeka" Gjilan, Faculty of Economics, Gjilan, Kosovo, 60000 \\ ${ }^{2,3}$ University of Prishtina, Faculty of Economics, Prishtinë, Kosovo, 10000 \\ Corresponding author's e-mail: skender.ahmeti@uni-pr.edu
}

\begin{abstract}
Unlike the other forms of investment strategies, foreign direct investment (FDI) involves the long-term commitment in the host country. FDI determinants are complex and multi-dimensional phenomena that result from both macro-economic and firm strategy considerations. The main objective of the present research is to review the empirical studies on FDI determinants in order to find out what motives international corporations are pursuing since the FDI policies and nation-specific business environment are directly affecting international corporations' activity involvement. The literature and document review research method is adopted for this research, and the research is refined by including only papers that contained empirical studies on FDI determinants. Research has been carried out using secondary data drawn from a diverse pool of materials, including books, journals and other credible reports from international institutions. This research concludes the evidence of the mixed results on such a linkage.
\end{abstract}

Keywords: Determinants, foreign direct investment (FDI), impact, multinational corporation (MNC), policy.

\section{INTRODUCTION}

There are several factors that impact and dictate the level of foreign direct investment (FDI) from a source into a host country. According to Lokesha and Leelavathy (2012), the characteristics of both micro and macro environment influence the outcome and the flow of capital. FDI determinants can also be grouped into three sections: policy framework, economic, and business facilitation (UNCTAD, 1998). Types of determinants identified in respect to different countries vary from one onto another (Wijeweera and Mounter, 2008). Moreover, according to Asiedu (2002), the determinants of FDI differ even across world regions. Therefore, understanding the determinants of FDI is of paramount importance for host countries to obtain an overview and a snapshot of the factors that impact a flow of capital into their economies. In turn, this allows respective governments to take appropriate measures concerning macroeconomic policies, to raise competitiveness in order to make their country more attractive than others (Bénassy-Quéré, Coupet, \& Mayer, 2007). 
FDI has played a major role in economic development and has challenged the traditional approach of host countries with regard to trade liberalization. Many countries that needed to absorb foreign direct investment have undergone structural reforms and changes to increase competition by creating friendly domestic investment policies, ensuring a higher degree of protection and providing various incentives to make their countries attractive for potential investors (Paez, 2011). There is an uncompromising economic and financial struggle between developed and developing countries to attract foreign companies to invest in their markets. This race is very challenging, laborious, difficult, and often outweighs the legal and moral norms of doing business internationally to prevail in this direction. According to the United Nations World Investment Report, developed countries are dominating by the level of financial capital from FDI. FDI flows are shown in Fig. 1.

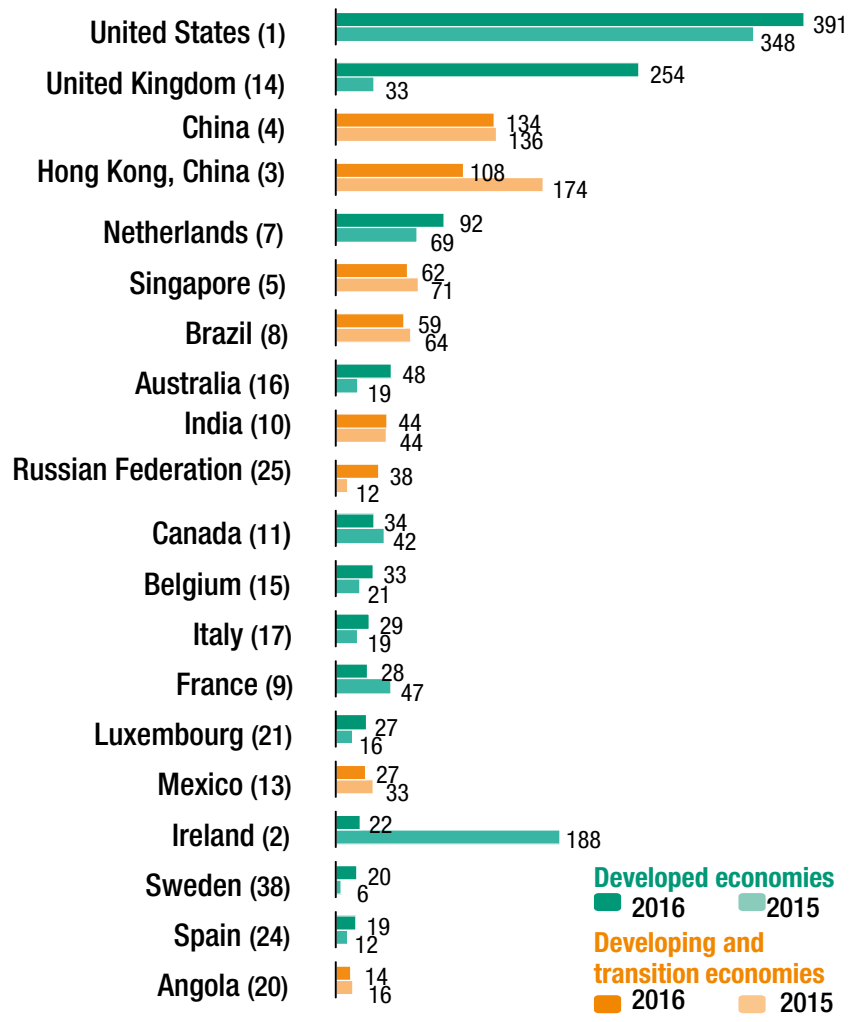

Fig. 1. FDI flows, top 20 economies, 2015 and 2016 (\$ Billion).

Source: UNCTAD $(2017 ; 12)$.

Figure 2 reflects the FDI performance index in developed and developing countries. The index shows the value of FDI that the countries draw in relation to Gross Domestic Product (GDP). In this case, as it is seen, developing countries have gradually increased the performance index, while developed countries have had a decline in the index. However, in the total value as reflected in Fig. 1, this has not been translated successfully since developed countries dominate the ability to attract foreign capital to their markets. FDI performance index in developed and developing economies is shown in Fig. 2. 


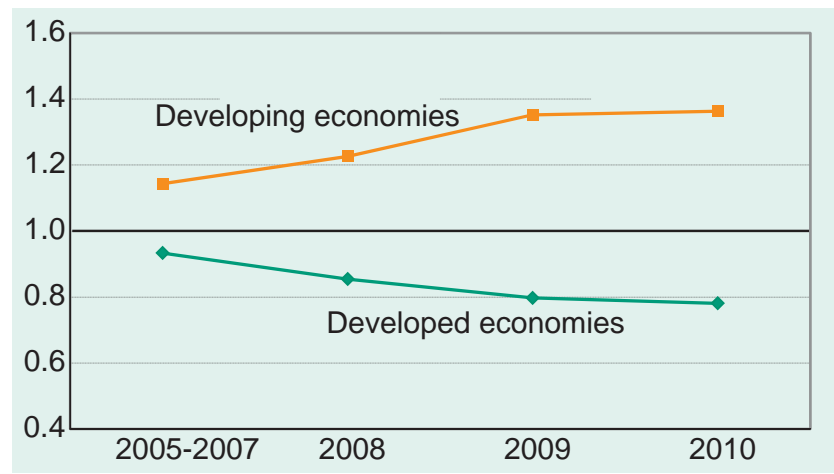

Fig. 2. FDI performance index in developed and developing economies. Source: UNCTAD $(2011 ; 5)$.

FDI in real estate still remains an unexplored topic so far unlike the FDI in general. Only a few studies have dealt with the impact of FDI in real estate. What makes investments in real estate significant is the investment character associated with it. As such, this investment is considered to be of a fixed nature and immobile. It is also very costly, durable and a risky investment (Gotham, 2006). The interest of US investors has shifted to the foreign markets in real estate since 1985. Moshirian and Pham (2000) have found that the decline in US stock exchange has been positively linked with the FDI in real estate sector by US companies abroad. Moreover, their findings show that financial wealth in US, FDI in manufacturing and banking, bilateral trade of US have contributed significantly to the expansion of foreign investments of US companies in international markets in the real estate sector. The empirical linkage of FDI in real estate and international tourism has been explored by Fereidouni and Al-Mulali (2014). Their study covers the OECD (Organisation for Economic Co-operation and Development) countries, and has shown a positive relationship amongst them.

The main objective of the present study is to review the empirical studies on FDI determinants in order to see what motives multi-national corporations (MNCs) are pursuing since the FDI policies and business environment are directly affecting MNCs' activity involvement.

The literature and document review research method is adopted for this study, and the research is refined by including papers that contained empirical studies on FDI determinants. These papers include empirical studies on different countries around the world that differ in size, economic development, infrastructure, labour cost and quality and trade openness. A qualitative approach will be adopted in the present study given the actual nature and the scope of the research. Qualitative research is best suited for the study because of the distinctive objective to provide a thorough understanding and interpretation of a phenomenon in the social world by learning the histories, experiences and perspectives of participants included in the study (Ritchie et al., 2013). Data used for the research comes from a multiple range of sources that have a very high degree of credibility and reliability, and which have been scrutinized by other respective bodies for accuracy and quality purposes. This includes various academic journals, books and publications. To ensure that research carries a very high degree of critique, when reviewing the empirical studies on FDI determinants, the analysis is divided into meaningful pieces and described accordingly to facilitate understanding. The analysis also 
entails supporting and opposing empirical findings on FDI determinants from a wide range of sources.

\section{TRADE OPENNESS}

According to Dowrick and Golley (2004), trade openness reflects the ratio of total trade within an economy. In other words, it represents the sum of total exports and imports to GDP. Literature relating to determinants, views trade openness as an important variable that influences the nature and level of FDI inflows. Factors that influence openness include both trade barriers and trade restrictions imposed by host countries. Unfavourable trade restrictions that run counter to multi-national corporations' interests tend to increase trade barriers for accessing the host country's markets. Ultimately, such a situation impacts their decision-making processes on the basis of investment. However, the relevance of trade openness is perceived differently by MNCs and depends on the investment type they ought to engage in. While some firms prefer more liberalized markets with minimum trade barriers to reduce transaction costs, others aspiring towards export related investments are more in favour of host markets that impose barriers and restrictions on trade against imports coming from competitors in order to reap and maximise existing possible profits in the domestic markets (Asiedu, 2002).

There is a general consensus on the perceived relevance of trade openness to attract foreign investors in the host countries (Oman, 2000; Cohen, 2007; Dunning and Lundan, 2008). The more changes and policies governments institute that lead to openness of their economies, the greater the likelihood of receiving large sums of FDI in terms of both quantity and quality. However, empirical studies examining its impact show different results. Nurudeen et al. (2011) and Seetanah and Rojid (2011), by studying the FDI determinants in Nigeria and Mauritius respectively, show a strong link between trade openness and the level of inflows. Although the model employed for Mauritius was differenced vector autoregressive (DVAR), in the case of Nigeria, both ordinary least squares (OLS) and error correction techniques (OCT) were used.

However, other studies relating to Malaysia using the OLS model (Sharma, Nayagam, \& Chung, 2012) and Central and Southeastern Europe (CSE) employing the OLI framework (Mateev, 2009) found out that trade openness did not have a statistically significant impact on inward FDI in respective countries, despite its influential role. It has been indicated that in the case of CSE, the variable might have been correlated with other factors that influence investment decisions. The study on Malaysia highlights the issue with the use of the model and specification of proxies included in the analysis, given the fact that many other determinants appeared to be insignificant as well. Moreover, Azam and Lukman (2010) using a quantitative approach found that trade openness has been a significant determinant for India from 1971 to 2005. 


\section{LABOUR COST}

This variable is mainly proxied by wage rate and refers to the percentage change of labour cost in a host country. It is widely believed that cheap labour cost is inclined to encourage MNCs to invest in foreign markets given the opportunity to cut down on production costs. By comparison, higher labour associated costs tend to generate opposite effects (Baker, 1999; Cohen, 2007). However, empirical studies depict heterogeneous effects on the relationship between labour cost and FDI inflows.

The relationship between FDI and wage rates seems to follow the related trend both in developed and less developed countries (LCDs). Wijeweera and Mounter (2008) using a Vector Auto Regression (VAR) model show that wage rate in Sri Lanka is the most important determinant that impacts inward FDI. Shamsuddin's (1994) study of 36 LCDs demonstrates that high wages negatively impact inward FDI. On the other hand, Sahoo's (2006) study using the Dynamic Panel Data Model (DPDM) reveals that FDI inflow is positively linked with the wage rates in reference to skilled labour markets in South Asia, given the large supply of skilled labour force whose expertise is relevant for the success of MNCs in the region. The market prices of skilled labour force in this region still represent just a small proportion in comparison with developed economies. Moreover, Vijayakumar et al. (2010) have found that labour cost is negatively correlated with inward FDI in the BRIC countries.

\section{MARKET SIZE}

The literature shows that market size can be proxied by GNP, GDP per capita or GDP. This is considered to be among the most important FDI determinants for MNCs that seek to expand their operations into foreign markets. Market sizes really do matter for many MNCs given the prospects to reap large sums of profits. Therefore, sizeable markets are bound to attract a greater number of foreign firms and thus raise competitiveness. The larger the market, the more opportunities for MNCs to achieve their economies of scale and decrease production associated costs (Cohen, 2007).

However, the relevance of market size dissipates in reference to export based MNCs that do not have the prime target marketplaces in the host countries, when deciding to invest abroad, as shown by Kyereboah-Coleman and Agyire-Tettey (2008). Their study highlights that MNCs may engage in FDI to access other intermediate market for export related purposes. Moreover, given the relevance of government policies regarding stimulation of FDI influx in a host country, market size may have the potential to generate growth as long as the domestic institutional framework and macroeconomic environment do not run counter to MNCs' short and long-term strategic objectives. Countries like Singapore and Malaysia, despite their small economies compared to Argentina, Brazil and India, are still capable of competing strongly because of more friendly FDI policies (Oman, 2000). The positive effects of market size with regards to inward FDI have been confirmed by numerous studies of various economies regardless of their size (Shamsuddin, 1994; 
Vijayakumar, Sridharan, \& Rao, 2010). Moreover, Azam and Lukman (2010) showed that market size had been highly significant for India's inward FDI from 1971 to 2005.

On the other hand, Seetanah and Rojid's (2011) study and that conducted by Asiedu (2002) reflect a negative correlation for Mauritius and sub-Saharan Africa countries, respectively. The latter study attempts to justify findings given the perceived risk of the region by MNCs. However, unlike Africa, the country of Mauritius has been quite successful in attracting foreign investors despite the relatively small market size because of existing good opportunities to attract export based MNCs.

\section{LABOUR QUALITY}

A high-skilled labour force is more inclined to adapt to new changes and, thus, is more productive compared to low-skilled employees. The attitude and perspective of MNCs towards the availability of labour quality in the host countries vary depending on the pursuit of their strategic objectives and the industries involved. While market seeking firms may not be concerned about labour quality, the efficiency seekers undoubtedly target markets with an abundant skilled labour force due to the nature of their operations. In other words, manufacturers operating in the clothing industry along with other MNCs who attempt to achieve economies of scale are not concerned with the quality, unlike high-tech industries (Dunning \& Lundan, 2008).

Seetanah and Rojid (2011) found the quality of labour to be among the most important FDI determinants in Mauritius. Iwai and Thompson (2012), by studying the impact of labour quality on the inflows in the developing countries, showed that quality of human capital was pivotal to attracting larger sums of FDI. However, Lin (2011), using firm level data across various regions and industries in China, found uneven results on the impact of labour quality. Nevertheless, the author highlights the need for China to invest in education in order to improve quality especially for technology based sectors and strengthen the ability to attract more FDI.

\section{INFRASTRUCTURE}

The quality of infrastructure is an important determinant that can dictate the pace of development, output levels and growth rates (Kirkpatrick, Parker, \& Zhang, 2006). The nature of infrastructure on a host country can impact MNCs' level of productivity and efficiency and, thus, ultimately determine the FDI inflows and investment types. According to Kumar (2006), infrastructure contributes to FDI growth if all other variables that impact inflows remain constant. Moreover, export based MNCs carefully consider the availability of infrastructure of a host country in order to access other markets given the relevance of transport, telecommunications, water and power supply. The more individual governments invest in infrastructure that can match with the nature of MNCs' strategic objectives, the greater the opportunities to attract larger numbers of prestigious corporations because of an adequate investment climate. Baker (1999) argues that 
developed economies have continuously succeeded in attracting larger sums of FDI compared to less developed countries partly because of advantages in infrastructure.

Zhou et al. (2002), by studying the determinants of Japanese FDI in China, found that infrastructure had played a pivotal role and had an enormous impact on the inflows. The study included 2,933 cases in over 27 provinces and highlighted the relevance of established Special Economic Zones (SEZ) and Opening Coastal Cities (OCC). Many other studies have confirmed the relevance of infrastructure as having a positive significant impact on inward FDI (Vijayakumar et al., 2010; Nurudeen, Wafure, \& Auta, 2011; Seetanah and Rojid, 2011).

Other research that involved a very high number of countries in their samples shows different results. Vogiatzoglou (2007) found that infrastructure had no statistically significant impact on inward FDI in South and East Asia. Similar findings were reached by Mateev (2009) in regards to CSE. The latter study attempts to justify such results by stating that infrastructure is deemed to be an imperfect proxy and easily correlated with other variables that influence investment decisions, when a larger number of countries with distinctive characteristics are included in the same sample.

\section{TAX RATE}

Host country's policies that relate to fiscal incentives affect the level of inward FDI. Firms usually seek host markets with lower tax rates in comparison with their source countries. The structure of tax rates (be it corporate, income or property tax) and their implications on MNCs' profit margins are considered thoroughly before any investment decision is undertaken. Governments in respective host countries aim to make a balance between tax incentive rates and the need to collect a desirable amount of income that is affordable from the MNCs' perspective in order to provide a competitive environment (UNCTAD, 2000). In addition, host countries establish free trade zones (Rogers and Wu, 2012) and SEZ (Zhou, Delios, \& Yang, 2002) to provide tax relief in order to attract a larger number of MNCs.

The variable tax rate is proxied by corporate tax in most of the empirical studies. Unlike other FDI determinants, the issue of tax rates has not been explored to a large extent. UNCTAD's (2000) report and Egger and Raff's (2011) research show a very high competition among different countries relating to the treatment of corporate tax to encourage FDI inflows in their respective markets. Similarly, a study by Zhou et al. (2002) shows how Chinese provinces compete against each other as far as tax incentives are concerned. Other studies conducted pertaining to Malaysia (Ang, 2007) and Pakistan (Azam and Lukman, 2010) show that low corporate taxes attract a higher influx of FDI.

\section{EXCHANGE RATES}

The relationship between FDI and exchange rates has been an area of interest of many policy makers across governments in different regions all over the world, in an attempt to create the legal framework to attract foreign investors. Among the earliest models to describe this link is the one developed by Cushman (1985) that 
takes into account three variables such as bilateral trade, real value of foreign exchange and expected currency risk. On the other hand, the model proposed by Froot and Stein (1991) attempts to explain FDI and exchange rate behaviour through capital market frictions that causes internal financing to be cheaper compared to external financing. Thus, such changes impact the level of FDI inflows in host countries. Both models attempt to describe the impact of exchange rate volatility and currency appreciation/or depreciation on the level of FDI inflows in a host country.

Looking at both the theory and empirical studies, it can be said that exchange rate regimes and the relationship between FDI and exchange rates have produced mixed results in the field. Xing (2005) argues that China's success in the recent decades is associated with its currency exchange policy. Keeping it pegged to the US dollar and intervening regularly in the market to weaken its currency have made China among the most attractive FDI destinations worldwide. This view is also supported by Abbott et al. (2012). Analysing the data on 70 developing countries from 1985 to 2004, the scholars found out that countries with floating currency regimes had not been able to perform at the same level with countries that had fixed currency systems. In contrast, Nyarko et al. (2011) found out that exchange rate regimes did not show any correlation with the levels of FDI inflows in Ghana.

On the other hand, Dewenter (1995) demonstrated that depreciation of the USD had a positive effect on absorbing higher levels of FDI in the USA. Baek and Okawa (2001) showed that Yen appreciation against other Asian currencies enabled Japanese MNCs to increase FDI in respective markets due to such differences in exchange rates. Similar findings have been reached by Takagi and Shi (2011) using panel data from the period of 1987-2008 of Japanese FDI on nine Asian economies. However, their scope of research was broader as it looked upon the impact of volatility and crisis on the FDI. The scholars concluded that higher volatility led to higher FDI inflows and that the Asian crisis did not appear to have any significant impact on the Japanese FDI flows.

\section{CONCLUSION}

There are mainly four important underlying locational determinants of FDI: the motives of multi-national corporations, the size of multi-national corporations, investment sector, and entry modes of FDI. Empirical studies conducted so far on the determinants of FDI include a whole range of different independent variables that influence the flow of capital. Variables included in the data panel can be subdivided into groups to obtain in-depth understanding. Some of the past studies on the area of FDI determinants focus on the institutional factors, while others focus on socio-political factors. However, the selection of variables for either is subject to the researchers' perspectives. The main objective of the present study has been to review the empirical studies on FDI determinants in order to find out what motives international corporations are pursuing in such a dynamic business environment. The importance of these determinants continuously changes in the process of dynamic economic environment evolvement. Semantically, these 
determinants are mainly firm-level considerations. However, the fundamental principle is host nation's influence.

From the above review of the empirical studies on the FDI determinants, it can be concluded that researchers have come up with mixed evidence. While some of the determinants in some countries have been linked positively with the inflows of the levels of FDI, in other countries the linkage has been either negative or neutral. This study shows that market size does not ultimately determine the FDI inflows. Countries such as Singapore and Malaysia have been competing relatively well as oppose to other bigger economies. In addition, countries from Africa that are not considered safe have failed to attract foreign investments regardless of the size of their economies. Regarding the tax rate, it can be concluded that not only countries compete with each other by lowering taxes, but even regions as it is the case with China. Both labour quality and labour costs are the key incentives in developing countries to attract FDI. However, foreign investors are facing difficulties in finding qualified employees because of their education in countries such as China irrespective of low labour cost availability.

\section{REFERENCES}

Abbott, A., Cushman, D. O., \& De Vita, G. (2012). Exchange Rate Regimes and Foreign Direct Investment Flows to Developing Countries. Review of international economics, 20(1), 95-107. https://doi.org/10.1111/j.1467-9396.2011.01010.x

Ang, J. B. (2008). Determinants of Foreign Direct Investment in Malaysia. Journal of policy modeling, 30(1), 185-189. https://doi.org/10.1016/j.jpolmod.2007.06.014

Asiedu, E. (2002). On the Determinants of Foreign Direct Investment to Developing Countries: Is Africa Different? World development, 30(1), 107-119. https://doi.org/10.2139/ssrn.280062

Azam, M., \& Lukman, L. (2010). Determinants of Foreign Direct Investment in India, Indonesia and Pakistan: A Quantitative Approach. Journal of Managerial Sciences, 4(1).

Baek, I. M., \& Okawa, T. (2001). Foreign Exchange Rates and Japanese Foreign Direct Investment in Asia. Journal of Economics and Business, 53(1), 69-84. https://doi.org/10.1016/s01486195(00)00038-2

Baker, J. C. (1999). Foreign Direct Investment in Less Developed Countries: The Role of ICSID and MIGA. Greenwood Publishing Group.

Bénassy-Quéré, A., Coupet, M., \& Mayer, T. (2007). Institutional determinants of foreign direct investment. The World Economy, 30(5), 764-782.

Cohen, S. D. (2007). Multinational Corporations and Foreign Direct Investment: Avoiding Simplicity, Embracing Complexity. Oxford University Press.

Kyereboah-Coleman, A., \& Agyire-Tettey, K. F. (2008). Effect of Exchange-Rate Volatility on Foreign Direct Investment in Sub-Saharan Africa: The case of Ghana. The Journal of Risk Finance, 9(1), 52-70. https://doi.org/10.1108/15265940810842410

Cushman, D. O. (1985). Real Exchange Rate Risk, Expectations, and the Level of Direct Investment. The Review of Economics and Statistics, 67(2), 297-308. https://doi.org/10.2307/1924729

Dewenter, K. L. (1995). Do Exchange Rate Changes Drive Foreign Direct Investment? Journal of Business, 68(3), 405-433. https://doi.org/10.1086/296670

Dowrick, S., \& Golley, J. (2004). Trade Openness and Growth: Who Benefits? Oxford Review of Economic Policy, 20(1), 38-56. https://doi.org/10.1093/oxrep/20.1.38

Dunning, J. H., \& Lundan, S. M. (2008). Multinational Enterprises and the Global Economy. Edward Elgar Publishing.

Fereidouni, H. G., \& Al-mulali, U. (2014). The Interaction Between Tourism and FDI in Real Estate in OECD Countries. Current Issues in Tourism, 17(2), 105-113. 
Froot, K. A., \& Stein, J. C. (1991). Exchange Rates and Foreign Direct Investment: An Imperfect Capital Markets Approach. The Quarterly Journal of Economics, 106(4), 1191-1217. https://doi.org/10.2307/2937961

Gotham, K. F. (2006). The Secondary Circuit of Capital Reconsidered: Globalization and the US Real Estate Sector. American Journal of Sociology, 112(1), 231-275. https://doi.org/10.1086/502695

Iwai, N., \& Thompson, S. R. (2012). Foreign Direct Investment and Labor Quality in Developing Countries. Review of Development Economics, 16 (2), 276-290. https://doi.org/10.1111/j.14679361.2012.00661.x

Kirkpatrick, C., Parker, D., \& Zhang, Y. F. (2006). Foreign Direct Investment in Infrastructure in Developing Countries: Does Regulation Make a Difference? Transnational Corporations, 15(1), 143-171.

Kumar, N. (2006). Infrastructure Availability, Foreign Direct Investment Inflows and Their ExportOrientation: A Cross-Country Exploration. The Indian Economic Journal, 54(1), 125-144. https://doi.org/10.1177/0019466220060108

Lokesha, B. K., \& Leelavathy, D. S. (2012). Determinants of Foreign Direct Investment: A Macro Perspective. Indian Journal of Industrial Relations, 459-469.

Lin, F. (2011). Labor Quality and Inward FDI: A Firm-Level Empirical Study in China. China \& World Economy, 19(3), 68-86. https://doi.org/10.1111/j.1749-124x.2011.01243.x

Mateev, M. (2009). Determinants of Foreign Direct Investment in Central and Southeastern Europe: New Empirical Tests. Oxford Journal, 8(1), 133-149.

Moshirian, F., \& Pham, T. (2000). Determinants of US Investment in Real Estate Abroad. Journal of Multinational Financial Management,10(1), 63-72. https://doi.org/10.1016/s1042444x(99)00019-5

Nurudeen, A., Wafure, O. G., \& Auta, E. M. (2011). Determinants of Foreign Direct Investment: The Case of Nigeria. IUP Journal of Monetary Economics, 9(3), 50-67.

Nyarko, P. A., Nketiah-Amponsah, E., \& Barnor, C. (2011). Effects of Exchange Rate Regimes on FDI Inflows in Ghana. International Journal of Economics and Finance, 3(3), 277-286. https://doi.org/10.5539/ijef.v3n3p277

Oman, C. (2000). Policy Competition for Foreign Direct Investment: A Study of Competition Among Governments to Attract FDI. OECD Publishing.

Paez, L. (2011). Liberalizing Finance Services and Foreign Direct Investment. Basingstoke: Palgrave Macmillan. https://doi.org/10.1057/9780230316829

Ritchie, J., Lewis, J., Nicholls, C. M., \& Ormston, R. (Eds.). (2013). Qualitative Research Practice: A Guide for Social Science Students and Researchers. Sage Publications.

Rogers, C. L., \& Wu, C. (2012). Employment by Foreign Firms in the US: Do State Incentives Matter? Regional Science and Urban Economics, 42(4), 664-680. https://doi.org/10.1016/j.regsciurbeco.2012.04.006

Sahoo, P. (2006). Foreign Direct Investment in South Asia: Policy, Trends, Impact and Determinants (No. 56). ADB Institute Discussion Papers.

Seetanah, B., \& Rojid, S. (2011). The Determinants of FDI in Mauritius: A Dynamic Time Series Investigation. African Journal of Economic and Management Studies,2(1), 24-41. https://doi.org/10.1108/20400701111110759

Shamsuddin, A. F. (1994). Economic Determinants of Foreign Direct Investment in Less Developed Countries. The Pakistan Development Review, 33(1), 41-51.

Sharma, K., Nayagam, J., \& Chung, H. H. (2012). Determinants of Foreign Direct Investment in Malaysia: New Evidence From Cointegration and Error Correction Model. The Journal of Developing Areas, 46(1), 71-89. https://doi.org/10.1353/jda.2012.0004

Takagi, S., \& Shi, Z. (2011). Exchange Rate Movements and Foreign Direct Investment (FDI): Japanese Investment in Asia, 1987-2008. Japan and the World Economy, 23(4), 265-272. https://doi.org/10.1016/j.japwor.2011.08.001

UNCTAD (1998). World Investment Report 1998: Trends and Determinants. New York and Geneva: United Nations.

UNCTAD (2000). Tax Incentives and Foreign Direct Investment: A Global Survey. New York and Geneva: United Nations. 
UNCTAD (2011). World Investment Report: Non-Equity Modes of International Production and Development. New York and Geneva: United Nations Publication. ISBN 978-92-1-112828

UNCTAD (2017). World Investment Report: Investment in Digital Economy. New York and Geneva: United Nations.

Vijayakumar, N., Sridharan, P., \& Rao, K. C. S. (2010). Determinants of FDI in BRICS Countries: A Panel Analysis. International Journal of Business Science \& Applied Management, 5(3).

Vogiatzoglou, K. (2007). Vertical Specialization and New Determinants of FDI: Evidence From South and East Asia. Global economic review, 36(3), 245-266. https://doi.org/10.1080/12265080701561984

Wijeweera, A., \& Mounter, S. (2008). A VAR Analysis on the Determinants of FDI Inflows: The Case of SRI LANKA. Applied Econometrics and International Development, 8(1), 189-198.

Xing, Y. (2006). Why is China so Attractive for FDI? The Role of Exchange Rates. China Economic Review, 17(2), 198-209. https://doi.org/10.1016/j.chieco.2005.10.001

Zhou, C., Delios, A., \& Yang, J. Y. (2002). Locational Determinants of Japanese Foreign Direct Investment in China. Asia Pacific Journal of Management, 19(1), 63-86. https://doi.org/10.2139/ssrn.305346

\section{AUTHORS' SHORT BIOGRAPHIES}

Arben Sahiti, MSc, is an Assistant at the Faculty of Economics, University "Kadri Zeka" in Gjilan, and Doctoral student at the Faculty of Economics, University of Prishtina. He obtained the Master of Science degree with merits in the field of Finance, Accounting, and Management from Bradford School of Management, University of Bradford in the United Kingdom, and the Bachelor of Science degree from Rochester Institute of Technology (RIT), USA, with the major in Management and a minor in Public Policy. He has participated in the international scientific conferences in Italy, Spain and Turkey. He is the author and co-author of several scientific publications. Since 2015, he has been a Board Member at the University "Kadri Zeka" in Gjilan.

E-mail: arben.sahiti@uni-gjilan.net

ORCID iD: https://orcid.org/0000-0002-5429-7626

Skender Ahmeti, Dr., is a Professor (since 2002) at the Faculty of Economics, Department of Banking, Finance and Accounting at the University of Prishtina. He has obtained Doctoral and Master degrees from the Faculty of Economics at the University of Prishtina. From 1 October 2009 to 15 March 2016, he held the position of Dean in two consecutive mandates at the Faculty of Economics, University of Prishtina. Professor Ahmeti has extensive experience in the public sector in Kosovo. From 1 September 2002 to 15 May 2006, he served as a permanent Secretary at the Ministry of Trade and Industry, Government of Kosovo. Moreover, he was a Political Advisor to the Minister of Energy and Mining at the Government of Kosovo from 1 January 2008 to 30 September 2009. He is the author of four books of the University level, and of several scientific research journals.

E-mail: skender.ahmeti@uni-pr.edu

Hysen Ismajli, Assoc. Prof., Dr., received the Bachelor degree in Economics from the University of Prishtina, the Faculty of Economics, in 1982 and the Master degree in Economics from the University of Zagreb, the Faculty of Economics, in 1986. He received the Doctoral degree in the field of Banking, Finance and Accounting from the University of Prishtina, the Faculty of Economics, in 2001. He has been full-time faculty member since 2002, at the Faculty of Economics, University of Prishtina. From 2006 to 2009, he was a Vice-Dean at the Faculty of Economics, University of Prishtina. He was a Chairman of the Kosovo Board on Standards for Financial Reporting and a Chairman of the Audit Licensing Commission and Auditing Companies (20042006). Moreover, he was a member of the Governmental Commission for Law Drafting of Enterprises in 2004. He currently teaches auditing and financial analysis courses.

E-mail: hysen.ismajli@uni-pr.edu 